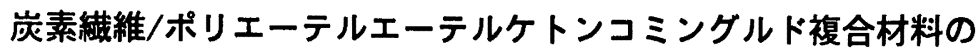 熱膨張係数
}

\author{
尹 吴圭 ${ }^{* 1} \cdot$ 高橋清久*1
}

（受付 1992 年 7 月 9 日・蕃査終了 1992 年 11 月 24 日）

\begin{abstract}
要 旨 炭素䄉維とポリエーテルエーテルケトン (PEEK) フィラメントとのコミングルド糸から作製した一方 向および二方向複合材料の熱凌張係数を測定し，炭素㵶維/PEEK プリプレグの一方向複合材料および直交積層板

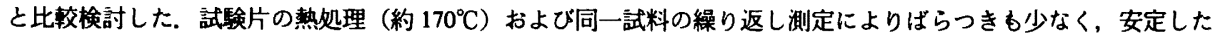
データが得られた。 これは再現性のあるデータを得るためには必要不可欠であった。一方向コミングルド複合材料 の織維方向熱膨張係数は全温度域でプリプレグより低い値を示し， $T_{8}$ 以上では大きく减少した. 二方向コミングル ト複合材料では、繶密度の高い経系方向が緯系方向より低い熱膨張係数を示したが、これは直交積層板とほば同じ 値であった. 複合材料の䄉維方向熱膨張保数の温度依存性はU字形を示した。この現象は，炭素緎維自体の織維方 向熱膨張俰数が温度依存性をもつと仮定することによって正確な理論的予測が可能となった。
\end{abstract}

1 緒言

炭素織維強化プラスチック (CFRP) の熱膨張係数は 絧維方向で著しく小さい特長をもち, 厳しい熱的環境に さらされる宇宙関連機器の寸法安定性や内部残留応力,

その結果起こりうる熱劣化などに関連して特に重要と なっており", 幅広く研究されてきだ) 。).

炭素䄉維とポリエーテルエーテルケトン (PEEK) と の複合材料は，炭素織維/エポキシ複合材料と比べて耐 熱性, 而湿性, 保存安定性, および破壊勒性などに優れ た先端複合材料として注目されている7)。炭素緎維/ PEEK 複合材料では, PEEK 樹脂の炭素緎維間への含浸 を容易にするために, プリブレグに代わる方法としてコ ミングルド系を用いた成形法が検討されている8). コミ ングルド系を用いた成形法は，織布または組み紐技術と 組み合わせて複雑な形状の 3 次元構造複合材料”の成形 にあ応用できる利点がある. 複合材料の熱膨張挙動は他 の材料との組み合わせにおいても非常に重要であり, コ ミングルド糸から成形した複合材料についても熱膨張挙 動を検討する必要がある.

本報告では炭素織維と PEEK フィラメントからなる コミングルド系を用いて一方向および二方向複合材料を 作製し，その熱膨張係数の温度依存性を，炭素繊維/ PEEK プリプレグから作製した一方向および直交積層 板と比較する. またこれらの実験データの理論的予測の 可能性についてあ检討を加える.

*1 名古屋工業大学材料工学科（\$66 名古屋市昭和区御器所 町)

\section{2 実医}

\section{1 試料}

種々の炭素織維/PEEK 複合材料を用いて熱膨張係数 を測定した. Table 1 に使用した試料を示す.プリプレグ 複合材料は APC-2 (ICI 社製) を用いて作製した. APC2 中の炭素紻維は米国 Hercules 社製の AS-4 (PAN 系, 東レ(株)製トレカT300 相当) であり, PEEK 樹脂は 150 Gである. コミングルド複合材料は, 炭素縅維と PEEK フィラメントからなるコミングルド系（フランス Schappe 社製, シャッペスパン $1800 \mathrm{~d}$ ）を用いて成形した. コミングルド糸中の炭素織維はドイッ Enka 社製のすの で，東レ(株)製トレカ T300に相当する物性をもち, PEEK 織維は, ICI 社製の樹脂 $(150 \mathrm{G})$ をドイッの Höchst 社が紡系したものである. 一方向コミングルド 複合材料は経糸としてコミングルド系, 緯糸として PEEK 系（帝人(株)製 $70 \mathrm{~d}$ ）を用いた平織布を積層した ものであり, 二方向コミングルド複合材料は経系, 緯系 とあにコミングルド系を用いだ．. ただし，二方向コミ ングルドの場合，1インチ当たりの織密度が経系（17.5 本) の方が緯糸 (13.5 本) より高い (Fig. 1). また二方向 コミングルドは成形のとき, 樹脂の流れによって織密度 の低い緯系の配列が乱れやすいため，測定値のばらつき が大きかったが, 本実験では経糸と緯糸がほぼ $90^{\circ} の$ 角 度をむっている部分から試料を切り出して用いた. コミ ングルド系中の PEEK 樹脂は熱プレス成形により, 融 けてマトリックスになる.

\section{2 試料作製方法}

Table 1 に示したように, 所望の厚さに達するまで積 


$$
\text { 尹・高橋 }
$$

Table 1. Specimens used in the experiment

\begin{tabular}{|c|c|c|c|c|}
\hline $\begin{array}{c}\text { Specimen } \\
\text { number }\end{array}$ & Specimen & $\begin{array}{l}\text { Layup relative to } \\
\text { CTE direction }\end{array}$ & $\begin{array}{l}\text { Volume fraction } \\
\text { of carbon fiber }\end{array}$ & No. of plies \\
\hline 1 & PEEK & - & - & - \\
\hline 2 & U-D Prepreg & $0^{\circ}$ & \multirow{4}{*}{62} & \multirow{4}{*}{16} \\
\hline 3 & U-D Prepreg & $90^{\circ}$ & & \\
\hline 4 & 2-D Prepreg & $\left(0^{\circ} / 90^{\circ}\right) 4 \mathrm{~s}$ & & \\
\hline 5 & 2-D Prepreg & $\left(90^{\circ} / 0^{\circ}\right) 4 \mathrm{~s}$ & & \\
\hline 6 & U-D Commingled & $0^{\circ}$ & \multirow{2}{*}{60} & \multirow{2}{*}{18} \\
\hline 7 & U-D Commingled & $90^{\circ}$ & & \\
\hline 8 & 2-D Commingled & Warp direction & \multirow{2}{*}{63} & \multirow{2}{*}{14} \\
\hline 9 & 2-D Commingled & Weft direction & & \\
\hline
\end{tabular}

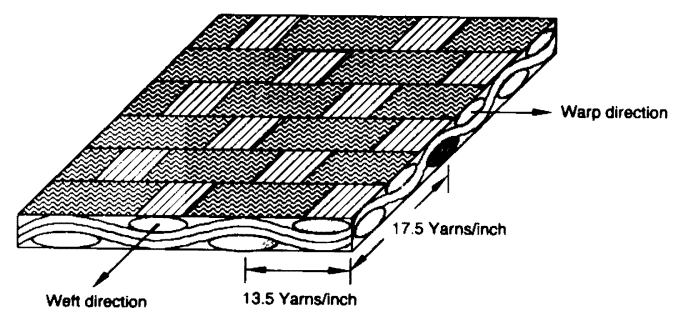

Fig. 1. 2-Dimensional (2-D) commingled composite.

層した試料を，離型剤（平泉洋行(株)製フリコート44） を塗った鋼製の板にはさみ、これをポリイミト（宇部興 産(株)製ユーピレックス）の真空バッグに入れる。この 真空バッグを $200^{\circ} \mathrm{C} に$ 予熱したプレス機に載せ，真空に 引きながら $200^{\circ} \mathrm{C}$ から $2.5^{\circ} \mathrm{C} / \mathrm{min}$ の速度で $400^{\circ} \mathrm{C}$ まで昇 温する. その後, 酸化防止のため室素ガスを吹き込み, 自然冷却 $\left(2^{\circ} \mathrm{C} / \mathrm{min}\right.$ で降温) して約 $100^{\circ} \mathrm{C}$ まで温度が低 下してから試料を取り出した，圧力はプリプレグの場合 $400^{\circ} \mathrm{C}$ まで $6 \mathrm{~kg} / \mathrm{cm}^{2}$ で加圧を続け，その後加圧を止める と 30 分ほよ゙で $2 \mathrm{~kg} / \mathrm{cm}^{2}$ に低下した。試料をプレス機か ら取り出すまでこのままの圧力を保った。 ただし，コミ ングルド複合材料は圧力が低いとボイドができやすく， 均一な試料ができにくいため, 一方向コミングルドは 20 $\mathrm{kg} / \mathrm{cm}^{2}$ を, 二方向コミングルドは $50 \mathrm{~kg} / \mathrm{cm}^{2}$ の圧力を加 えた.

複合材料の寸法は $100 \mathrm{~mm} \times 5 \mathrm{~mm} \times 2 \mathrm{~mm}$ とし, 長さ $(100 \mathrm{~mm})$ 方向に沿って熱膨張係数を測定した．ただし， 試料 No. 1 の PEEK 樹脂（住友べークライト(株)製）は 厚さ $1 \mathrm{~mm}$ の平板を用いたため, 試料の寸法を $200 \mathrm{~mm}$ $\times 4 \mathrm{~mm} \times 1 \mathrm{~mm}$ とした。

2.3 測定方法

TMA/SS120C（セイコー電子工業(株)製）を用いて測 定を行った，測定温度範囲は $-150^{\circ} \mathrm{C}$ から $200^{\circ} \mathrm{C}$ までと し, 昇温速度は $2^{\circ} \mathrm{C} / \mathrm{min}$ とした。 試験片は測定時以外は

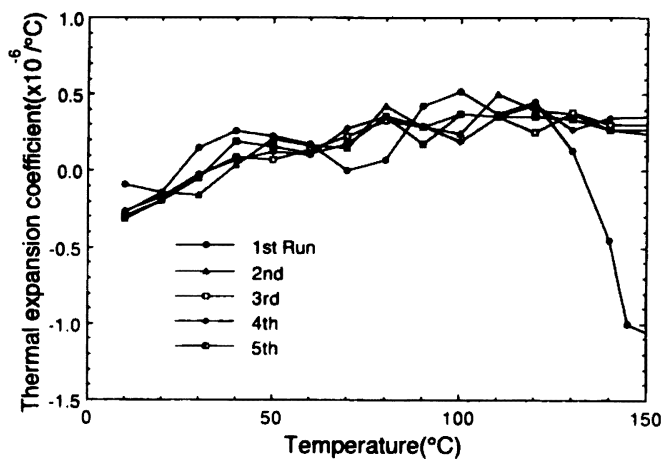

Fig. 2. Effect of run times on the CTE parallel to the fiber direction of a U-D prepreg composite.

デシケータ中に保管し水分の影隌を極力排除するように 注意した。 また測定を開始する前にも PEEK 樹脂の $T_{8}$ $\left(145^{\circ} \mathrm{C}\right)$ 上り $20 \sim 30^{\circ} \mathrm{C}$ 高い温度で約 15 分間加熱して水 分などを取り除いた後, 液体窒素を用いて $8^{\circ} \mathrm{C} / \mathrm{min}$ の速 度で降温した。この降温速度は自然冷却した場合の室温 付近までの平均速度である。 $-150^{\circ} \mathrm{C}$ まで领却し, 温度 が安定してから窒素ガス需囲気下で測定を開始した。

温度変化による試料の長さの変化を検出した後, 石英 ガラスの熱膨張(1)を補正し, 測定温度 $\pm 5^{\circ} \mathrm{C}$ の範囲で最 小二乗法により直線で近似して各々の温度での熱膨張係 数を求めた。

ただし，PEEK 樹脂は板状の試料を用いたため，熱膨 張係数を測定する際に, 複合材料の場合は圧縮モードで 測定したのに対し引張りモードで測定を行った。 また弾 性率は, DMS200 粘弾性測定装置（セイコー電子工業 （株)製）を用いて測定し，熱膨張俰数と同様に測定温度 $\pm 5^{\circ} \mathrm{C}$ の範井で最小二乗法によって各々の温度での値を 求めた。 


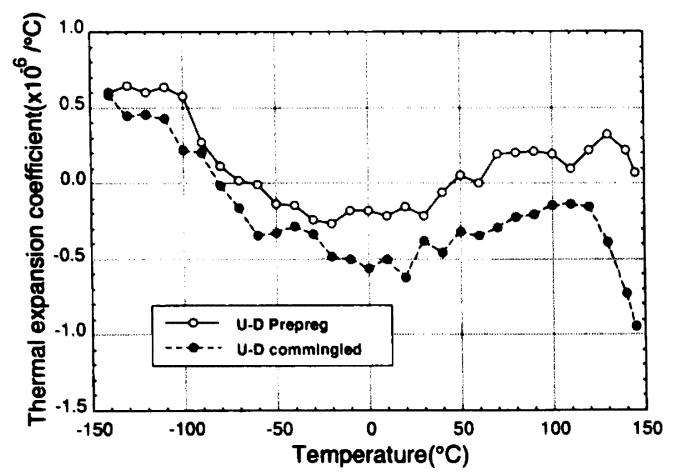

Fig. 3. CTE's parallel to the fiber direction of prepreg $(O)$ and unidirectional (U-D) commingled (O) composite.

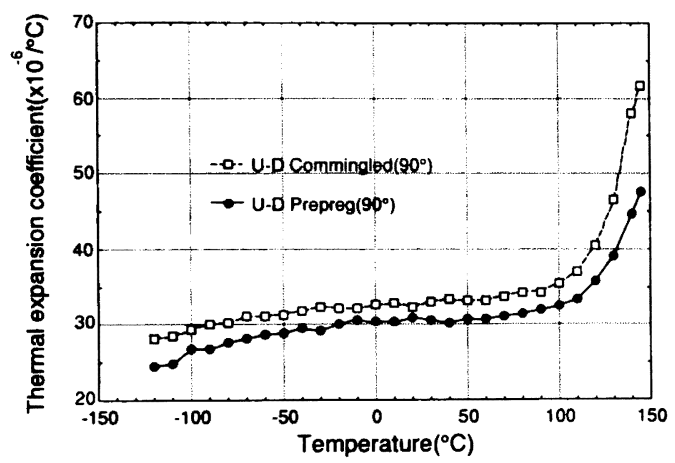

Fig. 4. CTE's transverse to the fiber direction of prepreg ( $($ ) and U-D commingled $(\square)$ composite.

\section{3 結果}

一方向プリプレグ複合材料の織維方向熱膨張係数 (CTE) を, $0^{\circ} \mathrm{C}$ から $160^{\circ} \mathrm{C}$ までの盜度範讲で, 同じ試料 を用いて 5 回まで絽り返し測定を行った (Fig. 2). 試料 は $T_{\mathrm{g}}$ 以上の温度で熱処理していないものである，最初 の測定ではばらつきが大きく， $T_{8}$ 付近で著しく低下する 傾向を示した. 2 回目以降の測定では $T_{\mathrm{B}}$ 付近での顕著な 減少が現れなくなり，1回目よりばらつきも少なく，安 定したデータが得られた。 これは $T_{\mathrm{g}}$ 以上に温度を上げ たことにより, 成形時, 試料中に残存していた内部歪が 解放され，それが 1 回目の CTEとして現れたものと考 えられる. 以下の結果はすべて $T_{\mathrm{B}}$ 以上の温度で熱処理 し, 2 回以上の繰り返し測定を行って, 安定な結果が得 られたデータだけを用いた。

一方向プリプレグの緉維方向 (Fig. 3，○) および一方 向コミングルドの織維方向 (Fig. 3, ○) 熱膨張係数は, 両方ともに $-50^{\circ} \mathrm{C}$ から $50^{\circ} \mathrm{C}$ の間で最も低い値をむつ U 字形を示しており, 一方向コミングルドが全温度域で一

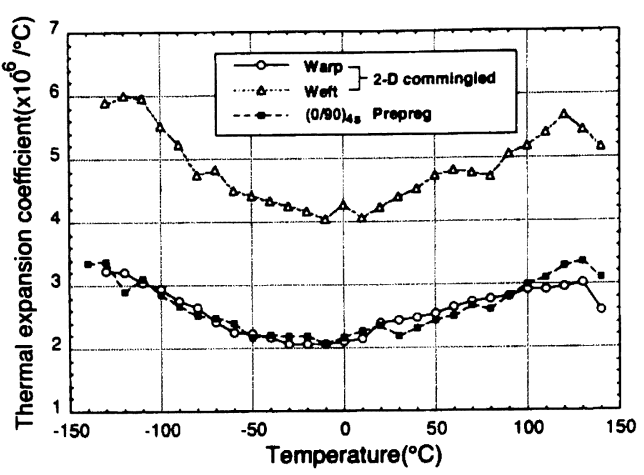

Fig. 5. CTE's of 2-D prepreg composite ( $\square$ ) and 2-D commingled composite in the warp direction $(O)$ and weft direction $(\triangle)$.

方向プリプレグより低い値を示している. さらに一方向 コミングルドは $130^{\circ} \mathrm{C}$ 付辺から急激に减少し，コミング ルド系中の炭素㵶維に撚りがかかっていることによる配 向分布の影響が現れている ${ }^{12)}$. 一方向プリプレグ試料の 熱膨張係数の温度依存性で観測されるU 字形は Barnes ら"の結果と一致する.

一方向プリプレグおよび一方向コミングルド試料の横 方向熱膨張係数 (Fig. 4) は一方向複合材料に表れる典型 的パターンを示しており, 一方向コミングルドは一方向 プリプレグより高い熱膨張係数を示している.これはコ ミングルド複合材料の炭素絨維の撚りによるものではな く体積分率が低いことに起因するものと考えられる.

プリプレグの直交積層板 (Fig. 5, 口) あ Fig. 3 と同様 のU字形を示している. 試料 No. 4 (Table 1) の直交積 層板は, 試料 No. 5 よりわずかながら高い熱膨張係数を 示したが, その差は非常に小さいため, Fig. 5 には示し ていない.

二方向コミングルド複合材料の経系方向熱膨張係数 (Fig. 5, ○, 試料 No. 8) は, 直交積層板とほぼ同じ值を 示している. 一方の緯系方向 (Fig. 5, $\triangle$, 試料 No. 9) は 経糸方向より高い熱膨張係数を示し, 温度変化に対する 熱膨張係数の変動も大きい.これらの結果は経糸方向と 緯系方向との織密度の違いによるあのと考えられる.

\section{4 考察}

マトリックスの PEEK 樹脂の熱膨張係数は温度が上 昇するにつれて徐々に増加し，ガラス転移温度を越える と急激に大きくなる (Fig. 6a). 一方, 弾性率は熱膨張係 数之全く反対で, $T_{\mathrm{g}}$ 以上で大きく減少する (Fig. 6b). こ れらは複合材料と同様に $T_{\mathrm{g}}$ 以上の温度で熱処理した後 の結果である. PEEK 樹脂の結晶化度は DSC (セイコー 電子工業(株)製, DSC220C) で測定した結果, 約 20\%で あって, 結晶化度 $20 \%$ のときの弾性率の温度変化に関 

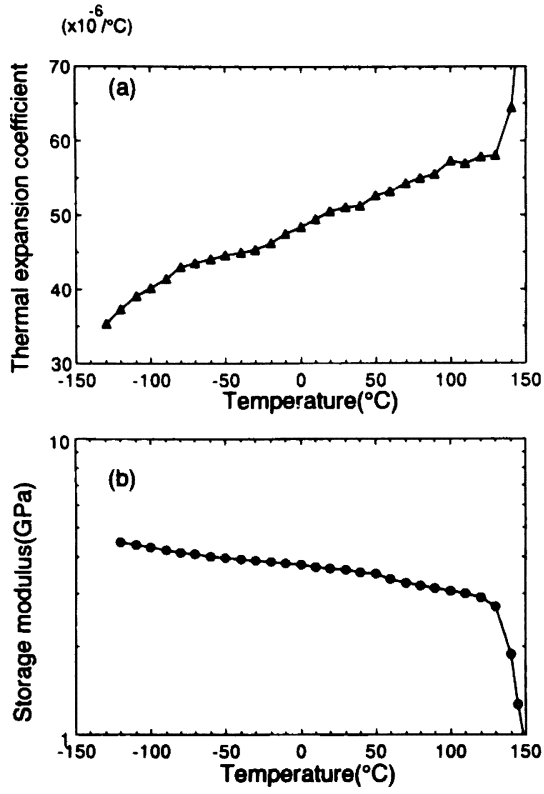

Fig. 6. (a) CTE and (b) storage modulus of PEEK resin.

する Chapman ら ${ }^{13)}$ の報告と Fig. 6b はほぼ一致する. 筆 者らは Fig. 6 の PEEK 樹脂の熱膨張係数および弾性率 を利用し, 炭素䄉維の熱膨張係数および弾性率, 炭素織 維と PEEK 樹脂のポアンン比は温度変化に関係なく一 定であると仮定して, 複合材料の熱膨張係数の理論値を 計算した ${ }^{12)}$. 計算には Eshelby の理論(4)を拡張した拡張 等価介在物法 ${ }^{(5)}$, 16)を用いた。この結果, 横方向熱膨張係 数は理論値とほぼ一致するが, 䄉維方向は大きな差が あった. 一方向プリプレグ複合材料の織維方向熱膨張係 数の理論値と実験値を Fig. 7 に比較する. 実験値はU 字 形を示しているのに対して，理論値は $T_{\mathrm{B}}$ までほぼ一定 値を示している.これは熱膨張係数の温度依存性が U 字形を示す全ての試料, No. 4, 5, 6, 8, および9 (Table 1) に表れる現象である.

複合材料の織維方向熱膨張係数はいわゆる複合則を用 いることにより簡単に計算できる.

$$
\alpha_{\mathrm{L}}^{\mathrm{c}}=\frac{E_{\mathrm{m}} \alpha_{\mathrm{m}} V_{\mathrm{m}}+E_{\mathrm{L}}^{\mathrm{f}} \alpha_{\mathrm{L}}^{\mathrm{f}} V_{\mathrm{f}}}{E_{\mathrm{m}} V_{\mathrm{m}}+E_{\mathrm{L}}^{\mathrm{f}} V_{\mathrm{t}}}
$$

ここで $a$ は熱膨張係数， $E$ はヤング率であり， $f, m$, およ びcはをれぞれ織維, マトリックスおよび複合材料を示 す.また $\boldsymbol{L}$ は緎維方向を表し， $\boldsymbol{V}$ は体積分率である.こ の式から織維の弾性率が大きいと, 複合材料の紻維方向 熱膨張係数は樹脂の弾性率および熱膨張係数の変化にあ まり影厩されないことが分かる。したがって，マトリッ クスの熱膨張係数及び弾性率のデータのみを用いては

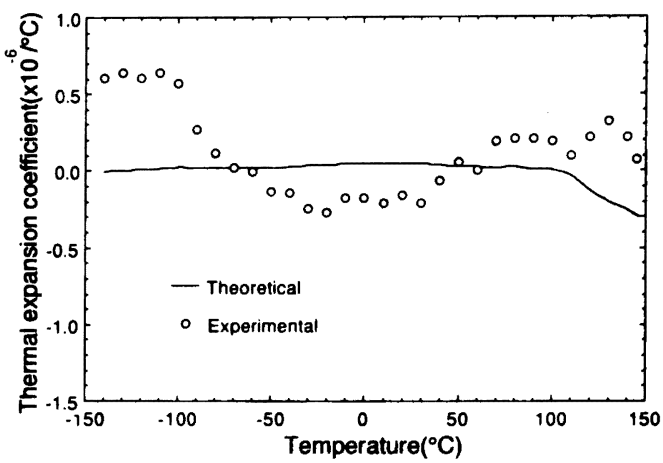

Fig. 7. Comparison of experimental CTE parallel to the fiber direction of the prepreg composite with theoretical prediction. The CTE and modulus of the carbon fiber were assumed to be constant independently of the temperature.

Fig. 7 のようにプリプレグの織維方向熱膨張係数の正し い予測ができない，逆に，炭素緎維の弾性率は PEEK 樹 脂より数十倍高いため, 紻維方向熱膨張係数 $\alpha$ [が変わ ると, 複合材料の熱膨張係数は大きく変化する. した がって, 試料 No. 2, 4, 5, 6, 8, および 9 の U 字形を示す 熱膨張係数は炭素䄉維自体の緎維方向の熱膨張係数の影 響によるものと考えられる。 そこで拡張等価介在物法を 用い, Fig. 3 および Fig. 4 のプリプレグの熱膨張係数 データを利用して炭素織維の熱膨張係数の温度依存性を 求めた. 織維のアスペクト比が無限大のとき,一方向複 合材料の熱膨張係数は次式で与えられる ${ }^{17}$.

$$
\begin{aligned}
\alpha_{\mathrm{L}}^{\mathrm{c}}-\alpha_{\mathrm{m}}= & \frac{V_{\mathrm{f}}}{R}\left[\left(C_{1}+C_{2}\right)\left(\alpha_{\mathrm{L}}^{\mathrm{f}}-\alpha_{\mathrm{m}}\right)+C_{3}\left(\alpha_{\mathrm{T}}^{\mathrm{f}}-\alpha_{\mathrm{m}}\right)\right] \\
\alpha_{\mathrm{T}}^{\mathrm{c}}-\alpha_{\mathrm{m}}= & \frac{V_{\mathrm{f}}}{R}\left[\left\{C_{4}-\frac{\nu_{\mathrm{m}}\left(1-V_{\mathrm{f}}\right)}{1-\left(1-2 \nu_{\mathrm{m}}\right) V_{\mathrm{f}}} C_{2}\right\}\left(\alpha_{\mathrm{L}}^{\mathrm{f}}-\alpha_{\mathrm{m}}\right)\right. \\
& +\left\{\frac{1-\nu_{\mathrm{m}} \nu_{\mathrm{LT}}^{\mathrm{f}}}{\nu_{\mathrm{LT}}^{\mathrm{f}}-\nu_{\mathrm{m}}} C_{3}-\frac{2\left(1-\nu_{\mathrm{m}}\right) V_{\mathrm{f}}}{1-\left(1-2 \nu_{\mathrm{m}}\right) V_{\mathrm{f}}} C_{\mathrm{L}}\right\} \\
& \left.\times\left(\alpha_{\mathrm{L}}^{\mathrm{f}}-\alpha_{\mathrm{m}}\right)\right]
\end{aligned}
$$

ここで $C_{i}$ および R は織維と PEEK 樹脂の弾性率および ポアソン比, 織維の体積分率で表される定数であり, 次 のように与えられる。

$$
\begin{aligned}
R= & \frac{E_{\mathrm{m}}}{E_{\mathrm{L}}^{\mathrm{f}}}\left(1-V_{\mathrm{f}}\right) C_{1}+V_{\mathrm{f}}\left(C_{1}+C_{\mathrm{L}}\right) \\
& +\frac{1+\nu_{\mathrm{m}}+\left(1-\nu_{\mathrm{m}}\right) V_{\mathrm{f}}}{2\left(\nu_{\mathrm{LT}}^{\mathrm{f}}-\nu_{\mathrm{m}}\right)} C_{3}-\frac{2 \nu_{\mathrm{m}} \nu_{\mathrm{TL}}^{\mathrm{f}} V_{\mathrm{f}}}{2 \nu_{\mathrm{TL}}^{\mathrm{f}}+\nu_{\mathrm{m}} \nu_{\mathrm{TT}}^{\mathrm{f}}-\nu_{\mathrm{m}}} C_{4} \\
C_{1}= & E_{\mathrm{m}} E_{\mathrm{L}}^{\mathrm{f}}\left(1-\nu_{\mathrm{TT}}^{\mathrm{f}}-2 \nu_{\mathrm{m}} \nu_{\mathrm{TL}}^{\mathrm{f}}\right)\left(1-V_{\mathrm{f}}\right) \\
C_{2}= & E_{\mathrm{T}} E_{\mathrm{L}}^{\mathrm{f}}\left(1+\nu_{\mathrm{m}}\right)\left\{1+\left(1-2 \nu_{\mathrm{m}}\right) V_{\mathrm{f}}\right\} \\
C_{3}= & 2 E_{\mathrm{m}} E_{\mathrm{T}}^{\mathrm{f}}\left(\nu_{\mathrm{tT}}^{\mathrm{f}}-\nu_{\mathrm{m}}\right)\left(1-V_{\mathrm{f}}\right) \\
C_{4}= & E_{\mathrm{m}} E_{\mathrm{L}}^{\mathrm{f}}\left(2 \nu_{\mathrm{TL}}^{\mathrm{f}}+\nu_{\mathrm{m}} \nu_{\mathrm{TT}}^{\mathrm{f}}-\nu_{\mathrm{m}}\right)\left(1-V_{\mathrm{f}}\right)
\end{aligned}
$$




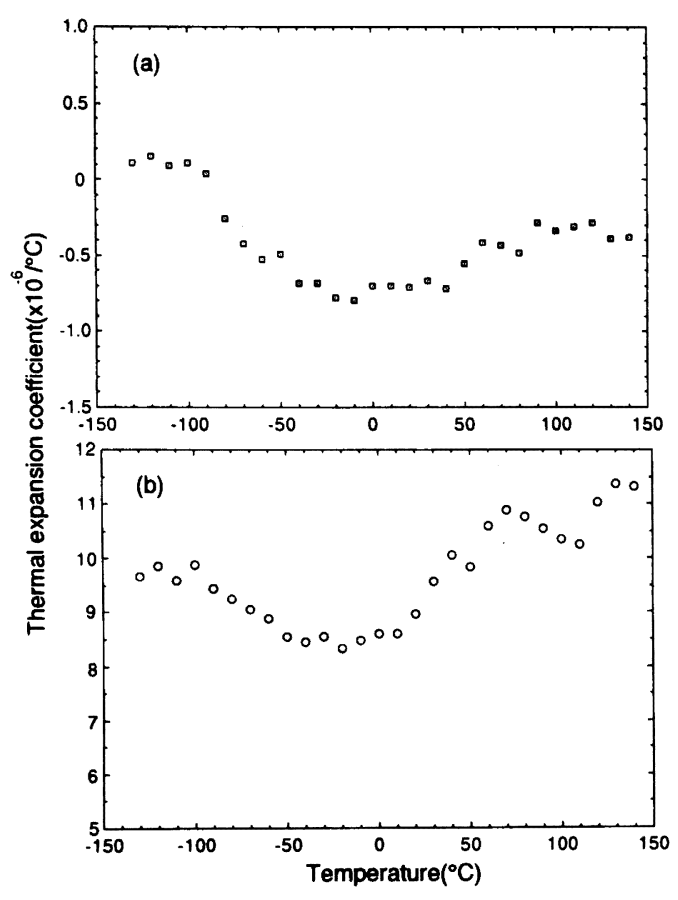

Fig. 8. Theoretical CTE's of carbon fiber calculated by Eshelby's equivalent inclusion method. (a) Longitudinal and (b) transverse direction.

ここでレはポアソン比を示す.

Fig. 3, 4 のプリプレグの熱膨張係数および Fig. 6 の PEEK 樹脂の熱膨張係数と弾性率のデータを式 (2) と (3)に代入し連立すると，炭素緎維の紻維方向および横 方向熱膨張係数が求められる. Fig. 8 にその結果を示す. 計算に用いた弾性係数は Ishikawa $e t$ el $^{18}$. の実験デー夕 を参考にして決定した.

$$
\begin{array}{ll}
E_{\mathrm{L}}^{\mathrm{f}}=230 \mathrm{GPa} & E_{\mathrm{T}}^{\mathrm{f}}=20 \mathrm{GPa} \\
\nu_{\mathrm{LT}}^{\mathrm{f}}=0.31 & \nu_{\mathrm{TT}}^{\mathrm{f}}=0.33 \\
\nu_{\mathrm{m}}=0.4 &
\end{array}
$$

ただし，これらのデータは東レ(竦製トレカ T300のもの であって,プリプレグおよびコミングルド系中の炭素䋐 維とは異なる. しかし，プリプレグの AS-4 およびコミ ングルド糸の炭素綫維は両方ともにPAN 系の高強度夕 イプであり，T300 とほぼ同程度の物性をもつことから， ここで引用した。

Fig. 8 の結果は式 (1) の複合則を用いてもほとんど変 わらない. また, Fig. 8 の結果を用いて, 直交皘層板 (試 料 No. 5) の熱膨張係数の理論値を実験値と比較した結 果を Fig. 9 にプロットした。実験値 (○) は Fig. 5 (口) をそのまま示したあのであり, 理論值（実線）とほぼ一

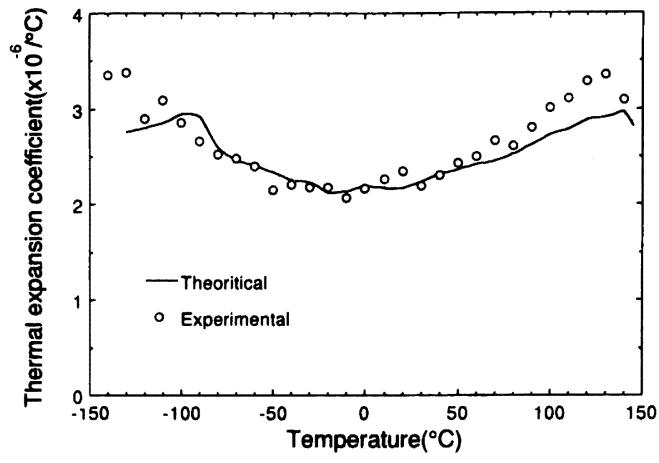

Fig. 9. Comparison of experimental CTE of the 2-D prepreg composite with theoretical prediction. The experimental data are from Fig. 5 (ם).

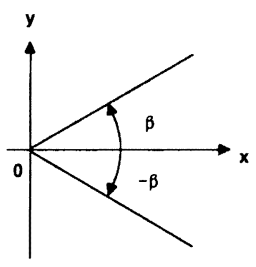

(a)

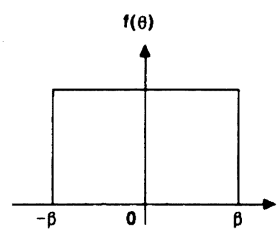

(b)
Fig. 10. (a) Fiber orientation limit angle $\beta$ and (b) the probability of orientation distribution.

致している. しかし炭素瀻維の紻維方向熱膨張係数が温 度依存性をむつならば, 一定と仮定した弾性率およびポ アンン比も温度変化によって変わるため, 炭素䄉維の紻 維方向熱膨張係数の温度依存性が必ずしも Fig. 8 のよj な結果になるとは限らないことも考えられる。

コミングルド糸は炭素綫維と PEEK フィラメントを ストレッチブレーキング法により長さ約 $12 \mathrm{~cm}$ に切断 し紡績したものであり，炭素䋞維に撚りがかかっている ため, 瀻維の配列は厳密には一方向でなく配向角に分布 をむつ. その配向分布角度は最大約 $10^{\circ}$ であった，炭素 織維のような異方性織維が配向分布をむつ場合，等価介 在物法による熱膨張係数の理論的な予測は困難である

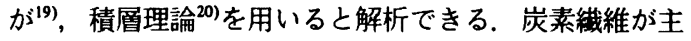
軸と $\theta(-\beta \leqq \theta \leqq \beta)$ の角度で平面的に配向し (Fig. 10a), さらにその配向分布 $f(\theta)$ が一定であるとき (Fig. 10b) の熱膨張係数を求め, 一方向コミングルド複合材料の䄉 維方向熱膨張係数 (Fig. 3, ○) と比較した. Fig. 11 にそ の結果を示す. 炭素擮維の熱膨張係数の温度依存性 (Fig. 8) を考虑し, 配向分布の最大角度を $\pm 10^{\circ}$ と仮定す ることにより, 各温度での熱膨張係数を予測した理論値 は実験値とほぼ良い一致を示した。 


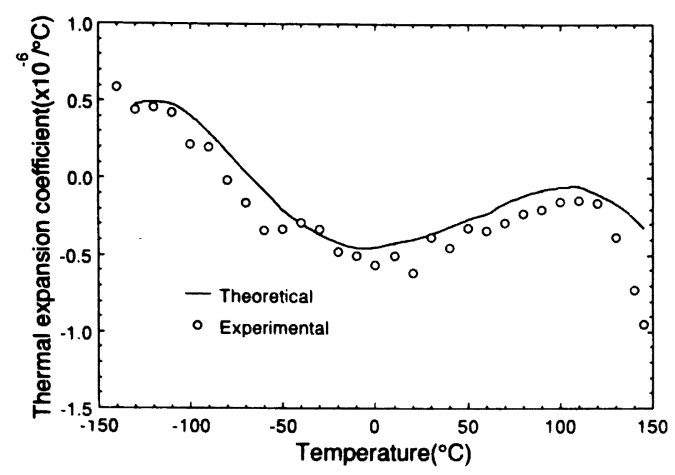

Fig. 11. Comparison of experimental CTE parallel to the fiber direction of the U-D commingled composite with theoretical prediction. The experimental data are from Fig. 3 (O).

経糸方向と緯系方向の織密度が等しい場合の二方向コ ミングルド複合材料は直交積首板と同様な熱膨張係数を 示すと見なすことができる21). したがって本報告で用い た二方向コミングルド複合材料の経方向（試料 No. 8) は織密度が高いため, 直交積層板（試料 No. 4, 5) より低 い熱膨張係数が予想される. しかし, 試料No. 5,8 の測 定値はほぼ同じとなっており (Fig. 5, 口と○)、これはコ ミングルド系の撚りと, 経系と緯系がクリンプをもつた め, 織維の横方向熱膨張係数も影響し, 高い熱膨張係数 を示したためと考えられる.

\section{5 結 論}

炭素織維と PEEK フィラメントからなるコミングル ド糸を用いて作製した一方向および二方向コミングルド 複合材料の熱膨張係数を測定し,プリプレグを用いて作 製した複合材料と比較検討した。 得られた結果を以下に 記す。

(1) 繰り返し測定によって, ばらつきも少なく安定 した熱膨張係数が得られた。.これは $T_{\mathrm{g}}$ 以上に温度を上 げたことにより, 成形時の内部歪が解放されたためと考 えられ，再現性のあるデータを得るためには必ず行う必 要があった。

(2) 一方向プリプレグ複合材料の䋐維方向熱膨張係 数を始め一方向コミングルドの織維方向, 直交積層板お よび二方向コミングルド複合材料など, 緎維方向の影響 を受ける場合の熱膨張係数の温度依存性は $\mathrm{U}$ 字形を示 した.

(3) 一方向コミングルド複合材料の絨維方向熱膨張 係数は全般的に一方向プリプレグより低い値を示し, 特 に $T_{\mathbf{b}}$ 付近で大きく隇少した.
(4) 二方向コミングルド複合材料の経系方向熱膨張 係数は高い織密度に起因して緯糸方向より小さい値を示 したが，直交積首板とほぼ同じとなった．また緯系方向 の測定値は経糸方向より温度依存性が大きかった。

(5) 結果 (2) に基づき, 炭素緎維の㵶維方向熱膨張 係数が温度依存性をもつと仮定することによって，一方 向コミングルドおよび二方向プリプレグ（直交皘層板） の熱膨張係数を正確に理論的に予測することが可能と なった。

的 辞 試料作製にご協力いただいた敷島紡績株式会社中央 研究所田中丸邦雄所長に感謝します。

\section{文献}

1) 北野武, “高性能高分子系複合材料”，高分子学会 (1990), p. 306.

2) O. Pirgon, G. H. Wostenholm, and B. Yates, J. Phys. D. Appl. Phys., 6, 309 (1973).

3) B. Yates, M. J. Overy, J. P. Sargent, and B. A. Macalla, J. Mater. Sci., 12, 718 (1977).

4) T. Ishikawa, K. Koyama and S. Kobayashi, J. Composite Mater., 12, 153 (1978).

5) J. A. Barnes, I. J. Simms, G. J. Farrow, D. Jackson, G. Wostenholm, and B. Yates, J. Composite Mater., 26, 2259 (1991).

6) J. M. Gaitonde and M. V. Lowson, Composite Sci. Technol., 40, 69 (1991)

7) J. T. Hartness, SAMPE J., Sep/Oct, 26 (1984).

8) A. Y. Lou, T. P. Murtha, J. E. O'Connor, and D. G. Brady, "Thermoplastic Composite Materials", L. A. Carlsson, Ed., Elsevier Science Publishers BV, Amsterdam, (1991) p. 183.

9）福多健二, 強化プラスチック, 32, 160 (1986).

10) H. Yoon and K. Takahashi, 䄉維学会誌, 47, 76 (1991).

11) R. K. Kirby and T. A. Hahn, Data Sheet for NBS SRM 739 dated 12 May 1971, Washington DC, USA

12）尹 昊圭, 高橋清久, 日本レオロジー学会誌, 21(1) (1993), 揭載予定.

13) T. J. Chapman, J. W. Gillespie Jr., J-A. E. Manson, and J. C. Seferis, J. Composite Mater. 24, 616 (1990).

14) J. D. Eshelby, Proc. Roy. Soc., (London), A 241, 376 (1957).

15) K. Takahashi, H. Harakawa, and T. Sakai, J. Compos. Mater., 14 (Suppl.), 144 (1980).

16）高橋清久, 尹 吴圭, 高分子論文集, 48, 595 (1991).

17）京野哲幸, 高橋清久, 材料, 38, 307 (1989).

18) T. Ishikawa, K. Koyama, and S. Kobayashi, J. Composite Mater., 11, 332 (1977).

19）尹 昊圭, 高橋清久, 日本レオロジー学会誌, 18, 117 (1990).

20) R. M. Jones, "Mechanics of Composite Materials", McGraw-Hill, New York (1975), Chapter 4.

21) T. Ishikawa and T.-W. Chou, J. Composite Mater., 17, 92 (1983). 


\section{Thermal Expansion Coefficients of Commingled Carbon Fiber/Poly(ether-ether-ketone) Composites}

Hogyu YoON*1 and Kiyohisa TAKAHASHI*1

${ }^{* 1}$ Department of Materials Science and Engineering, Nagoya Institute of Technology (Gokiso-cho, Showa-ku, Nagoya, 466 Japan).

Thermal expansion coefficients (CTE) of commingled composites manufactured from commingled yarns composed of carbon fibers (CF) and PEEK [poly(ether-ether-ketone)] filaments were measured and compared with those of CF/ PEEK prepreg composites. All specimens showed stable and non-scattered CTE data as a result of the thermal treatment or the repeating measurement on the same specimen. This procedure was necessary to obtain reproducible data. The unidirectional (U-D) commingled composite exhibited lower longitudinal CTE than the U-D prepreg composite, and showed a remarkable decrease of CTE at around $T_{\mathrm{g}}$ of PEEK resin. The CTE of the warp direction in 2-dimensional (2-D) commingled composite, that showed lower CTE than the weft direction due to the higher warp density, was found to be almost similar to that of 2-D prepreg (cross-ply) composite. Assuming the temperature dependence of CTE of the carbon fiber itself, theoretical predictions of CTE's of the U-D commingled and the 2-D prepreg composites were obtained in good agreement with experimental results.

KEY WORDS Carbon Fiber / Poly(ether-ether-ketone) Commingled Composite / Thermal Expansion Coefficient /

Temperature Dependence / Theoretical Prediction /

(Received July 9, 1992: Accepted November 24, 1992)

[Kobunshi Ronbunshu, 50(2), 73-79 (1993)] 